\title{
The Missing Left? \\ Economic Crisis and the Programmatic Response of Social Democratic Parties in Europe
}

\author{
Björn Bremer*† \\ European University Institute \\ bjoern.bremer@eui.eu
}

December 2017

Forthcoming in Party Politics

\begin{abstract}
How have social democratic parties responded to the recent economic crisis? For many observers, the Great Recession and the prevalence of austerity in response to it have contributed to a crisis of social democracy in Europe. This paper examines the programmatic response of social democratic parties responded to this crisis in eleven Western European countries. It uses an original dataset that records the salience that parties attribute to different issues and the positions that they adopt with regards to these issues during electoral campaigns and compares the platforms of social democratic parties before and after 2008. For this purpose, the paper disentangles economic issues into three different categories and shows that this is necessary in order to understand party competition during the Great Recession: while social democratic parties shifted to the left with regards to issues relating to welfare and economic liberalism, they largely accepted the need for budgetary rigour and austerity policies.
\end{abstract}

Keywords: Party systems, elections, party change/adaptation, economic issues, Europe

*Previous versions of this paper were presented at the International Conference of Europeanists 2016, the Annul Meeting of the American Political Science Association 2016, and at the London School of Economics and Political Sciences. I am very grateful for all comments that I have received at these occasions. Moreover, I thank Hanspeter Kriesi, Matthias Matthijs, Waltraud Schelkle, Michael Klitgaard, Per Andersson, Sebastian Diessner, Sean McDaniel, two anonymous reviewers, and the three editors of this special issue for excellent feedback on earlier drafts. All remaining errors are my own.

†The author gratefully acknowledges funding from the ERC Project "Political Conflict in Europe in the Shadow of the Great Recession" (Project ID: 338875) 


\section{Introduction}

The Great Recession was the deepest economic crisis in advanced capitalist countries since the Great Depression. 1 In Europe this economic crisis also led to a crisis of social democratic parties, which struggled to respond to the economic malaise ${ }^{2}$ Prior to 2008, they had mostly shifted towards the centre and embraced Third Way policies. However, the Great Recession that begun in 2008 raised new doubts about the merits of this shift. The break-down of the international financial system exposed the vulnerability of the existing economic order and created high unemployment and inequality. Moreover, in response to the European sovereign debt crisis governments across the continent implemented austerity policies, undermining the European welfare state that social democratic parties had built in the post-war era (Korpi, 1983; Stephens, 1979). How have social democratic parties responded to this crisis?

To answer this question, the paper examines empirically whether and to what extent social democratic parties changed their economic positions during the Great Recession. Although it is too early to tell what the long-term political consequences of the crisis will be, the purpose of studying this response is to understand how economic crises influence party competition in the short- and medium-term (also see Clements et al., 2017). The starting point for this analysis are two conflicting findings in the literature. First, some authors have found that parties hardly change their positions over time (e.g. Budge, 1994; Budge et al., 2001). In particular, social democratic parties are portrayed as parties with a strong ideology and close ties to social movements that constrain them in responding to changes in the economy (Adams et al., 2009). Other authors, in contrast, argued that social democratic parties have radically changed their positions in the last few decades. In response to globalisation, they shifted to the right resulting in a "neoliberal convergence" of centre-left and centre-right parties (e.g. Mishra, 1999, Glyn, 2001).

In this paper, I test which of these expectations holds with evidence from the Great Recession. I use an original dataset based on media analysis in 11 countries that allows me to compare the salience that parties attribute to different issues and the positions that they adopt with regards to these issues during electoral campaigns before and after 2008. Analysing this data, I present evidence that social democratic parties shifted their positions towards the left during the crisis, which is contrary to common perceptions in the media (Münchau, 2015; The Economist, 2016) and emerging research (English et al., 2016; Dalton, 2016). However, their positions diverged with respect to different issue categories. On the one hand, social democratic parties defended the welfare state

\footnotetext{
${ }^{1}$ The Great Recession is defined here as the economic crisis that begun in September 2008, when the US investment bank Lehman Brothers collapsed. It conceptualises both the 2008 financial crisis and the Euro crisis as one economic recession.

${ }^{2}$ I refer to 'centre-left', 'moderate left', and 'social democratic' parties interchangeably.
} 
and opposed economic liberalism after the 2008 financial crisis, which partly reverted their own Third Way. On the other hand, many parties also supported the reduction of government deficits and taxes during the crisis - that is, they joined the chorus of austerity that became the dominant tune during the Euro crisis. Hence, social democratic parties adopted positions with regards to the three different issue categories (welfare, economic liberalism, and budgetary rigour), which do not neatly align on a single left-right line of conflict. This suggests that party competition during the Great Recession was complex and cannot be represented on a single dimension (Otjes, 2016).

To make these arguments, the article proceeds in six steps. First, I briefly review the existing literature. Second, I set out my expectations about the response of social democratic parties to the Great Recession and formulate my hypotheses. Afterwards, I introduce my dataset and explain the methods that I use to analyse party competition. In section 5 and 6 , I proceed to present my empirical results. Combining descriptive analysis with regression analysis, I first examine the salience that social democratic parties attributed to economic issues during the crisis. Then, I analyse the position that these parties adopted with regard to economic issues. Finally, section 7 concludes.

\section{Party Positions, Issue Salience, and the Economy}

There is a large literature that studies the platforms on which political parties compete. Influenced by the median-voter theorem of Downs (1957), many scholars view parties as vote-seeking (e.g. Huber and Powell, 1994; McDonald and Budge, 2005). They argue that there is a close link between the positions that parties take and the preferences of the electorate. Consequently, party elites systematically respond to variations in the distribution of voters' preferences, which is a process that Stimson et al., 1995) called "dynamic representation." '3. However, given that large shifts in the distribution of voters' preferences are rare, the programmes of parties remain relatively stable over time. As a result, many scholars shifted their attention towards studying salience (Budge et al., 2001; McDonald and Budge, 2005; Bélanger and Meguid, 2008). They focused on "issue emphasis" (Budge and Farlie, 1983) because "[v]arying emphases on issues are by and large the only way that parties express their policy differences' (Budge et al., 2001, p.82). Based on the notion of "issue ownership" (Petrocik, 1996), parties are attributed different levels of competence in different policy areas and they have an interest to selectively emphasise those areas in which they outshine their competitors. However, the voters' prioritisation of different issues can change between elections (Petrocik, 1996, Petrocik et al., 2003,

\footnotetext{
${ }^{3}$ There is some evidence for the plausible alternative hypothesis that parties respond to fluctuations in the preferences or priorities of their constituencies and not the entire electorate (e.g Ezrow et al., 2011)
} 
Bélanger and Meguid, 2008). Thus, parties are expected to change the salience that they attribute to different issues, even if they hardly change their positions over time.

The conclusion that party positions are relatively stable is shared by two other strands of the literature. On the one hand, the classical work by Lipset and Rokkan (1967) argues that parties are rooted in cleavages. These cleavages are relatively stable over time and given that parties have distinct cleavage locations, they limit the positional manoeuvrability of existing parties in response to external shocks (Hooghe and Marks, 2018). On the other hand, other authors viewing parties as policy-seeking also consider the positions of parties relatively stable (Strøm, 1990; Müler and Strøm, 1999, Dalton and McAllister, 2015). From this perspective, the positions of parties reflect the beliefs of their elites, which, in turn, are shaped by the parties' core ideologies. Ideologies provide actors with a general frame of reference, which allow them to understand and interpret events Assuming that these ideologies are sticky, parties are not expected to radically change their positions, either. In particular, left-wing parties are resistant to change their position for two reasons (Adams et al. 2009). First, left-wing parties are historically more ideological than other parties. They were born from the labour movement in the 19th century and remained committed to engineering social change even after they had abandoned their revolutionary ambitions (Przeworski and Sprague, 1986). Second, social democratic parties have close ties to trade unions and social movements that restrict their ideological flexibility even if these ties have weakened in the last few decades (Kitschelt, 1994, Piazza, 2001).

However, the problem with many of these studies is that they examine party competition in a vacuum and ignore the role of contextual factors. Only recently authors have begun to explicitly study the importance of economic conditions for party competition (Ward et al., 2015, 2011, Haupt, 2010, Adams et al. 2009). Much of this research studies the effect of globalisation on political parties and it is closely related to research in political economy, which has argued that globalisation constrains state intervention in the economy (Berger, 2000, Strange, 1996). Paradoxically, this literature has also singled out social democratic parties to make their case (Scharpf, 1987; Garrett and Lange, 1991, Ward et al., 2011). Assuming that globalisation makes it increasingly difficult for social democratic parties to correct undesirable market outcomes, they abandoned their core ideologies and increasingly embraced orthodox policies. Thus, globalisation diminished the policy differences between the left and paved the way for a "neoliberal convergence" of mainstream parties (Mishra, 1999, Ross, 2000, Callaghan, 2000, Glyn, 2001; Pierson, 2001). Although some authors dispute this "neoliberal convergence" hypothesis (Allan and Scruggs, 2004, Burgoon, 2001; Boix, 1998), they often agree that globalisation forces parties to adapt their political programmes, albeit in a complex and variegated way. Political parties are seen as strategic actors that use different political programmes to respond to 
domestic and international economic changes. In principle, this approach is not necessarily contradictory to research, which finds that party positions are relatively stable: while many authors emphasising stability study the basic dimensional position of parties, those predicting change focus on individual issues. Still, the literature provides two different expectations about how social democratic parties respond to economic changes: some authors argue that party positions are stable and that parties only selectively emphasize and de-emphasize certain issues, whereas others argue that parties actually adapt their programmes in response to the domestic and international economic context. Which of these conclusions holds up when we consider the response of social democratic parties to the Great Recession?

\section{The Programmatic Response of Social Democratic Par- ties to the Great Recession: Some Expectations}

The Great Recession has been a structural break for the development of the advanced economies. It was triggered by the mortgage crisis in the United States and became a full blown financial crisis in September 2008, when the investment bank Lehman Brothers collapsed. This bankruptcy sent shock waves through the international financial system and created a deep economic recession across almost all advanced capitalist countries. Europe was hit especially hard because in 2010 the 'American' financial crisis turned into a 'European' sovereign debt crisis. The political repercussions of this crisis are still uncertain, but it is already becoming clear that the Great Recession was a critical juncture that has changed long-term trends of political conflict in Europe (Hernández and Kriesi, 2016).

One important trend prior to the Great Recession was the increasing importance of non-economic or cultural issues for party competition (Franklin et al., 1992, Kitschelt, 1994 Kriesi et al., 2008; Hooghe and Marks, 2009). Yet, the crisis increased economic grievances throughout Europe and presented all political actors with an acute set of economic problems. Given that materialist concerns become more important for the electorate during times of economic hardship (e.g. Margalit, 2013; Singer, 2011; Traber et al., 2017), I expect that all political parties attempted to capture the public mood and increased the salience of economic issues after 2008 (hypothesis 1a). Still, it is likely that the crisis did not effect all parties equally because parties 'own' different political issues (e.g. Petrocik, 1996, Green and Hobolt, 2008; Wagner and Meyer, 2014). Although the economy is usually addressed by all parties, social democratic parties are historically associated with issues relating to social solidarity. Therefore, I also expect that social democratic parties increased the salience of economic issues more than other parties, 
which are less concerned with social justice (e.g. Conservative parties) or more associated with non-economic issues (e.g. the Greens or the radical populist right), as expressed in hypothesis $1 b$.

Salience Hypothesis I (H1a): Social democratic parties increased the salience of economic issues in response to the crisis.

Salience Hypothesis II (H1b): Social democratic parties increased the salience of economic issues more than other parties, which are less associated with issues relating to social solidarity.

In response to the economic turmoil, I also expect that social democratic parties changed their positions on economic issues. Many studies showing that the positions of parties are relatively stable, focused their analysis on long-term trends during periods of relative economic stability. In contrast, a growing literature in political economy has emphasized the importance of crises as critical junctures (Capoccia and Kelemen, 2007; Collier and Collier, 1991). Politics may appear stable during "normal times" due to path-dependency (Pierson, 2000), but crises shake the foundations of existing social systems. The resulting uncertainty allows policy entrepreneurs to engineer institutional change (Capoccia, 2015) and often leads to institutional, political, and policy change with significant legacies (Gourevitch, 1986). They create the perfect pre-conditions for paradigm change, as outlined by Hall (1993), because the uncertainty opens up windows of opportunity, during which ideas can serve as explanations of what went wrong, and how to fix it (Blyth, 2002; Matthijs, 2011). For social democratic parties, the Great Recession should have been such a critical event because it provided them with a golden opportunity to renew their traditional socio-economic programmes, as expressed in hypothesis 2a. Importantly, for other parties this opportunity did not exist to the same extent. While some of them already had more leftist positions prior to the Great Recession (e.g. far left parties), other parties (e.g. conservative parties) could not shift their positions leftwards due to the pro-market ideologies that they adhere to. Hence, I expect that the effect of the crisis should have been particularly large for social democratic parties (hypothesis $2 \mathrm{~b})$.

Position Hypothesis I (H2a): Social democratic parties responded to the crisis by moving to the left on economic issues.

Position Hypothesis II (H2b): Social democratic parties responded to the crisis by moving to the left on economic issues more than other parties.

However, the impact of the crisis was not uniform across all economic issues. Importantly, in the wake of the crisis one has to distinguish between three issue categories: (1) issues that relate to the welfare state and redistribution; (2) issues that relate to eco- 
nomic liberalism; and (3) issues that relate to the budget of the government (see table 11. This distinction is necessary because in order to capture the complex political impact of the crisis. First, the crisis was widely narrated as a crisis that resulted from excessive liberalisation of the financial system (e.g. Blanchard et al., 2010, Bean, 2010). This presented centre-left parties with a window of opportunity to oppose economic liberalism and distance themselves from the causes of the Great Recession. Similarly, low-income households, which social democratic parties claim to represent, were particularly at risk during the Great Recession due to the increase in unemployment and economic uncertainty. Thus, the Great Recession also provided social democratic parties with an opportunity to renew their support for the welfare state. Yet, with regards to macroeconomic policies, social democratic parties had less lee-way to change their policies. Most governments stimulated the economy immediately after the financial crash in 2008 (Hall, 2013, Pontusson and Raess, 2012), but leading policy makers soon began to demand austerity when the financial crisis turned into a sovereign debt crisis. As Matthijs and McNamara (2015) critically point out, conventional wisdom held that this crisis was caused by excessive government debt and 'irresponsible' behaviour by the debtor countries. Social democratic parties in these countries were, thus, forced to accept austerity measures in return for bail-out packages from the European Union and the International Monetary Fund (e.g. PASOK in Greece, PS in Portugal, and PSOE in Spain).

Table 1: List of Economic Issue Categories (adopted from Kriesi et al. 2008)

\begin{tabular}{ll}
\hline \hline \multicolumn{1}{c}{ Categories } & \multicolumn{1}{c}{ Description of Left-Wing Positions } \\
\hline Welfare & $\begin{array}{l}\text { Support for the welfare state and redistribution } \\
\text { through taxes and benefits } \\
\text { Economic Liberalism }\end{array}$ \\
Opposition to competition, deregulation, and priva- \\
tization \\
$\begin{array}{l}\text { Opposition to a rigid budgetary policy and the re- } \\
\text { duction of taxes (without an explicit redistributive } \\
\text { character) }\end{array}$ \\
\hline \hline
\end{tabular}

Parties in creditor countries or outside the Eurozone also largely accepted this shift to austerity. For example, the German SPD already supported the introduction of a constitutional debt brake in 2009 and promised to reduce government debt as one of the key pillars of its economic programme in 2013 (Social Democratic Party of Germany, 2013). Similarly, the Labour party in the UK accepted the need for fiscal consolidation. The party opposed the spending cuts by the Conservative government, but it also adopted a fiscal commitment prior to the 2015 election promising to 'balance the books and deliver a surplus on the current budget and falling national debt in the next Parliament' (Balls, 2014). Consequently, we need to disentangle issues that relate to the government's budget from other economic issues. In particular, I expect that left-wing parties did not shift to the left with regards to budgetary issues during the crisis but that they addressed 
these issues more often in order to signal economic competence (Kraft, 2017) and to appeal to fiscally conservative voters, who favour balanced budgets. Facing attacks from other political parties, they attempted to present themselves as economically competent and responsible in this way. These expectations are summarised in hypotheses 3a and 3b.

Programmatic Differentiation Hypothesis I (H3a): Social democratic parties increased the salience of issues relating to budgetary rigour in response to the crisis.

Programmatic Differentiation Hypothesis II (H3b): Social democratic parties did not move to the left on issues relating to budgetary rigour in response to the crisis.

Still, there are reasons to believe that the expected shifts by social democratic parties, as expressed in hypotheses 1 to 3, did not happen in all countries equally. In particular, the depth and length of the crisis should have influenced the response of left-wing parties to the Great Recession. In countries that escaped the crisis relatively unscathed, leftwing parties had less reason to increase the salience of economic issues and change their position with regards to issues like welfare and economic liberalism. Importantly, while they might have also shifted to the left in the immediate aftermath of financial crisis, I expect that they moderated their positions again as the impact of the recession waned in their country. Therefore, in countries that were hit especially hard by the economic crisis, we can expect that parties altered their positions on the economy more fundamentally, which is formulated in hypothesis 4 .

Economic Conditionality Hypothesis (H4): The depth and length of the economic crisis influenced the effect of the crisis: in countries where the economic crisis was severe, social democratic parties changed salience and positions more than in countries where it was less severe.

\section{Data and Methods}

In order to analyse the programmatic response of social democratic parties to the Great Recession, I study the platforms on which parties compete before elections. Electoral campaigns provide a good indicator of party positions because parties have to develop a coherent programme prior to elections and, thus, their positions crystallise. In this article I use a new and original dataset that is an update to the dataset used by Kriesi et al. (2008, 2012). The data was collected by the POLCON project to study the political consequences of the Great Recession. It measures party positions by analysing how they are represented by the mass media during electoral campaigns. This type of data is appropriate for studying the response of parties to the crisis for three reasons. First, the 
data allows me to analyse both the salience that parties attribute to economic issues and the positions that they take towards these issues, which are important aspects of party competition in the 21st century. Second, the data shows the positions that parties adopt in public discourse and, thus, reflects the positions of parties with regards to the most important issues of the day. This should make any changes induced by the crisis more visible than in other sources. Finally, the data enables me to disentangle economic issues into different issue categories, which is necessary in order to understand party competition in the context of the economic crisis.

Unfortunately, the data also has some short-comings. Most importantly, media biases might misrepresent some actors and provide limited information about small parties and non-salient issues. Alternative data sources avoid such biases. In particular, the Manifesto Project (MARPOR) (Volkens et al., 2017) has created a large database that is commonly used to study party positions. However, this data cannot be used in this paper because the coding scheme does not capture positive and negative stances for all issues that are relevant for my analysis, which would directly allow for the calculation of positions (Gemenis, 2013 , Dolezal et al. 2014). Most importantly, the data from MARPOR does not allow me to disentangle economic issues as described above. Therefore, as suggested by Helbling and Tresch (2011), I use media analysis in order to study parties' positions on sub-issues instead.

Specifically, the following analysis is based on the detailed coding of newspapers during thirty-one election campaigns in eleven different Western European countries. These countries include seven Northern European countries (Austria, France, Germany, Ireland, Netherlands, Switzerland, and the United Kingdom) and four Southern European countries (Greece, Italy, Portugal, and Spain). In each country, I use the last election prior the beginning of the crisis in 2008, against which I compare all electoral campaigns that have occurred from 2009 to 2015.4 The newspapers that were used for this analysis and the detailed list of the electoral campaigns and their classification is included in appendix 1. From each newspaper, a representative sample of relevant articles is coded by means of core sentence analysis (Kleinnijenhuis et al., 1997; Kleinnijenhuis and Pennings, 2001), which records the relationship between a subject (an actor) and an object (another actor or an issue) on a scale from -1 to +1 . In total, the resulting dataset contains 81,159 core sentences and for each election I have, on average, 2136 core sentences. The actors mentioned in the newspapers are coded based on their party affiliation, while the issues were coded inductively and classified into more than 200 categories. From these categories, I created three meta-categories about the economy, as shown in appendix 2: welfare, economic liberalism, and budgetary rigour. Following (Kriesi et al., 2008), I assume that all

\footnotetext{
${ }^{4}$ Elections that occurred in 2008 are excluded from the analysis due to their proximity to the breakdown of Lehman Brothers in September 2008.
} 
other issues are either embedded in a second, cultural dimension of political conflict or in none of the two dimensions. 5

In order to test my hypotheses, I use the data to compute two key measures for each party for the individual issue categories: salience and left-right position (see appendix 3). Salience for each party on an individual issue is simply the share of core sentences that a party devotes to a given issue compared to all core sentences coded for that party during the election campaign. The left-right position for a party on a given issue is the average direction of all statements about that particular issue, which ranges from -1 to +1 , where -1 is the left end of the spectrum and +1 is the right end of the spectrum. Afterwards, I also calculate the salience and left-right position for every party on the aggregate level, i.e. for all economic issues. In this case, salience is simply the sum of the salience for all three issue individual categories. The aggregate left-right position for any given party is calculated as the mean of all statements from the three economic categories, weighted by the salience of the individual categories.

First, I use these measures descriptively to compare the strategies of left-wing parties before and after the beginning of the crisis. In each section, I start by analysing the aggregate changes, but I also analyse the changes with respect to each individual issue category in order to examine the sources of the aggregate changes. Second, I use regression analysis to test whether the effects of the crisis are statistically significant. For this purpose, my unit of the analysis is a given party for each national election campaign. In total, this gives me a dataset with 198 observations across eleven countries. Note that my data is heavily "cross-sectional dominant" (Stimson, 1985) but that it also has a time dimension. To account for this fact, I use generalised least square (GLS) regressions because it can be shown that GLS estimators are more efficient than ordinary least square (OLS) estimators, when there is a certain degree of correlation between the residuals in a regression model (Greene, 2012, p. 372) ${ }^{6}$ As listed in appendix 4, the dependent variables for my analysis are (1) the salience that parties attribute to economic issues and (2) the left-right position that parties take on these issues. My key independent variables are party family (operationalised as shown in appendix 5) and a dummy variable that equals one when the election occurred after 2008 and zero otherwise. The effect of the crisis on any given party family is then tested through an interaction effect between these two variables. To test the conditionality of the crisis effect, I use a three-way interaction term

\footnotetext{
${ }^{5}$ This approach excludes economic issues that have a European dimension from the analysis (e.g. Eurobonds or support for the European Stability Mechanism). These issues became more important during the crisis, but they were not politicised in the same way across all countries included in this study. Importantly, in some countries European integration is still more associated with cultural issues than with economic issues (Otjes and Katsanidou, 2017), which makes an analysis of European issues more difficult.

${ }^{6}$ As a robustness check, I repeated the analysis using an OLS estimator. The results are extremely similar to the ones shown here.
} 
between party family, my dummy variable, and the unemployment rate 7 Finally, I also include other control variables that could potentially explain party positions on economic issues, including unemployment, GDP growth, government debt and deficit, government status, and country fixed effects. Other confounding variables are not included in the regression model shown here due to the small number of observations ${ }^{8}$

\section{Social Democratic Parties and the Crisis: Changes in Issue Emphasis}

In response to the Great Recession political parties were forced to address 'old' economic issues (like unemployment) more resolutely, but they also had to find answers to 'new' issues (like bank bailouts or the stability of the financial system). As a result, the salience that mainstream parties attribute to economic issues increased during the crisis in almost all countries (figure 1). This change was large in countries that were hit particularly hard by the crisis (e.g. Italy, Spain, and Portugal), but the salience of economic issues also dramatically increased in other countries (Austria, Switzerland, and the UK). Moreover, this increase in salience was largely systemic, i.e. changes in salience were not idiosyncratic to individual party families. Instead, the salience of economic issues in the media increased for all party families and, in particular, mainstream parties moved in tandem in response to the crisis. It is, therefore, difficult to distinguish between an effect at the party level and an effect at the level of the party system descriptively.

In order to test whether the differences between party families are statistically significant, I use regression analysis, as described above. The results of this analysis are shown in model 1 of table 2. They indicate that far right parties as well as green parties consistently emphasized economic issues less than the moderate right (the baseline). Moreover, the crisis had a positive and statistically significant impact on salience, as indicated by the coefficient for the crisis dummy variable. Yet, all the interaction terms between party families and this dummy are small and not statistically significant, which indicates that the crisis did not systematically alter the pattern of party competition with regards to salience. In particular, the salience of economic issues for moderate left-wing parties and moderate right-parties increased in tandem in response to the economic crisis, which is

\footnotetext{
${ }^{7}$ The unemployment rate is used as an indicator for the depth of the economic crisis for three reasons. First, it measures the impact of the financial crisis on the real economy. Second, and related, the unemployment rate is a proxy for the level of economic grievances that the population of any country experiences during an economic crisis. Third, unemployment is a good measure because it is easily comparable across countries. Other possible specifications of this variable were used as a robustness check but they did not change the results (e.g. GDP growth, inflation, sovereign debt and deficit).

${ }^{8}$ Other variables were included in further models (e.g. Eurozone membership, being a recipient of bail-outs, the presence of far right and far left parties, or the type of economic system). None of these variables turned out to be significant.
} 
Figure 1: Issue Salience of All Economic Issues by Party Family by Country

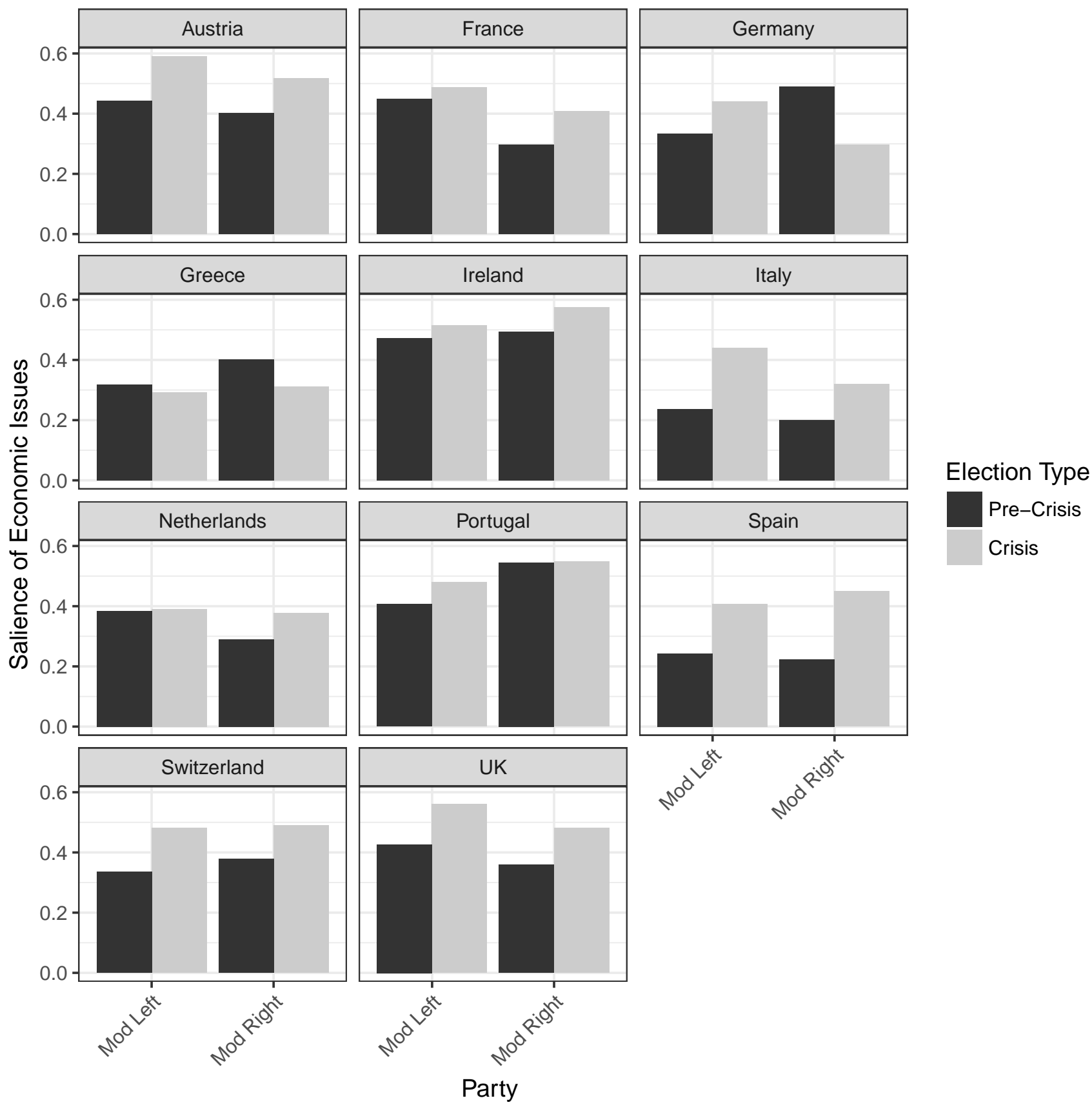

evidence against hypothesis $1 \mathrm{~b}$. Similarly, there is no evidence that the response of social democratic parties to the crisis was influenced by the strength of the crisis. The three-way interaction term in the second model in table 2 is not statistically significant, which suggests that the response of social democratic parties was similar in all countries independent of the depth of the crisis. 
Table 2: GLS Regression - Salience of Economic Issues by Different Party Families

\begin{tabular}{|c|c|c|c|c|c|}
\hline & \multicolumn{5}{|c|}{ Dependent Variable } \\
\hline & $\begin{array}{c}\text { Aggregate I } \\
(1) \\
\end{array}$ & $\begin{array}{c}\text { Aggregate II } \\
(2) \\
\end{array}$ & $\begin{array}{c}\text { Welfare } \\
(3) \\
\end{array}$ & $\begin{array}{c}\text { Eco Lib } \\
(4)\end{array}$ & $\begin{array}{c}\text { Budget } \\
(5) \\
\end{array}$ \\
\hline Far Right & $\begin{array}{c}-0.16^{* * *} \\
(0.06)\end{array}$ & $\begin{array}{c}-0.27 \\
(0.21)\end{array}$ & $\begin{array}{c}-0.04 \\
(0.04)\end{array}$ & $\begin{array}{c}-0.03 \\
(0.04)\end{array}$ & $\begin{array}{c}-0.08^{* * *} \\
(0.03)\end{array}$ \\
\hline Liberal & $\begin{array}{c}-0.05 \\
(0.06)\end{array}$ & $\begin{array}{c}-0.08 \\
(0.18)\end{array}$ & $\begin{array}{c}-0.0000 \\
(0.04)\end{array}$ & $\begin{array}{c}0.02 \\
(0.04)\end{array}$ & $\begin{array}{c}-0.07^{* *} \\
(0.03)\end{array}$ \\
\hline Moderate Left & $\begin{array}{c}-0.03 \\
(0.05)\end{array}$ & $\begin{array}{c}0.03 \\
(0.16)\end{array}$ & $\begin{array}{c}0.03 \\
(0.03)\end{array}$ & $\begin{array}{c}0.01 \\
(0.03)\end{array}$ & $\begin{array}{c}-0.07^{* *} \\
(0.03)\end{array}$ \\
\hline Far Left & $\begin{array}{c}-0.01 \\
(0.05)\end{array}$ & $\begin{array}{c}0.24 \\
(0.19)\end{array}$ & $\begin{array}{c}0.03 \\
(0.03)\end{array}$ & $\begin{array}{l}0.08^{* *} \\
(0.03)\end{array}$ & $\begin{array}{c}-0.11^{* * *} \\
(0.03)\end{array}$ \\
\hline Green & $\begin{array}{c}-0.18^{* * *} \\
(0.06)\end{array}$ & $\begin{array}{c}-0.26 \\
(0.18)\end{array}$ & $\begin{array}{c}-0.05 \\
(0.04)\end{array}$ & $\begin{array}{c}-0.05 \\
(0.04)\end{array}$ & $\begin{array}{c}-0.08^{* *} \\
(0.03)\end{array}$ \\
\hline Other & $\begin{array}{c}-0.16^{* * *} \\
(0.06)\end{array}$ & $\begin{array}{c}-0.02 \\
(0.19)\end{array}$ & $\begin{array}{c}-0.04 \\
(0.04)\end{array}$ & $\begin{array}{c}-0.05 \\
(0.04)\end{array}$ & $\begin{array}{c}-0.07^{* *} \\
(0.03)\end{array}$ \\
\hline Crisis Election & $\begin{array}{c}0.07 \\
(0.04)\end{array}$ & $\begin{array}{c}0.10 \\
(0.13)\end{array}$ & $\begin{array}{c}0.03 \\
(0.03)\end{array}$ & $\begin{array}{l}0.09^{* * *} \\
(0.03)\end{array}$ & $\begin{array}{c}-0.05^{* *} \\
(0.02)\end{array}$ \\
\hline Unemployment (t-1) & $\begin{array}{c}0.002 \\
(0.01)\end{array}$ & $\begin{array}{c}0.01 \\
(0.02)\end{array}$ & $\begin{array}{c}-0.003 \\
(0.004)\end{array}$ & $\begin{array}{c}0.003 \\
(0.004)\end{array}$ & $\begin{array}{c}0.003 \\
(0.003)\end{array}$ \\
\hline Inflation (t-1) & $\begin{array}{c}0.02 \\
(0.02)\end{array}$ & $\begin{array}{c}0.02 \\
(0.02)\end{array}$ & $\begin{array}{c}-0.01 \\
(0.01)\end{array}$ & $\begin{array}{c}0.01 \\
(0.01)\end{array}$ & $\begin{array}{c}0.01 \\
(0.01)\end{array}$ \\
\hline GDP Growth (t-1) & $\begin{array}{c}0.001 \\
(0.005)\end{array}$ & $\begin{array}{c}0.004 \\
(0.005)\end{array}$ & $\begin{array}{r}-0.002 \\
(0.003)\end{array}$ & $\begin{array}{c}0.003 \\
(0.003)\end{array}$ & $\begin{array}{c}-0.0000 \\
(0.003)\end{array}$ \\
\hline Gov Deficit (t-1) & $\begin{array}{c}-0.005^{* *} \\
(0.002)\end{array}$ & $\begin{array}{c}-0.005^{* *} \\
(0.002)\end{array}$ & $\begin{array}{c}0.001 \\
(0.001)\end{array}$ & $\begin{array}{c}-0.005^{* * *} \\
(0.001)\end{array}$ & $\begin{array}{c}-0.002 \\
(0.001)\end{array}$ \\
\hline Gov Debt (t-1) & $\begin{array}{c}-0.001 \\
(0.001)\end{array}$ & $\begin{array}{c}-0.001 \\
(0.001)\end{array}$ & $\begin{array}{c}-0.001 \\
(0.001)\end{array}$ & $\begin{array}{c}-0.001 \\
(0.001)\end{array}$ & $\begin{array}{c}0.0003 \\
(0.001)\end{array}$ \\
\hline Government (t-1) & $\begin{array}{c}-0.02 \\
(0.03)\end{array}$ & $\begin{array}{c}-0.02 \\
(0.03)\end{array}$ & $\begin{array}{c}-0.03^{*} \\
(0.02)\end{array}$ & $\begin{array}{l}0.03 \\
(0.02)\end{array}$ & $\begin{array}{c}-0.01 \\
(0.02)\end{array}$ \\
\hline Prime Minister (t-1) & $\begin{array}{c}-0.01 \\
(0.04)\end{array}$ & $\begin{array}{c}-0.02 \\
(0.04)\end{array}$ & $\begin{array}{c}0.02 \\
(0.03)\end{array}$ & $\begin{array}{c}-0.02 \\
(0.02)\end{array}$ & $\begin{array}{c}-0.01 \\
(0.02)\end{array}$ \\
\hline Far Right $\mathrm{x}$ Crisis Election & $\begin{array}{c}-0.03 \\
(0.07)\end{array}$ & $\begin{array}{c}0.02 \\
(0.22)\end{array}$ & $\begin{array}{c}-0.05 \\
(0.04)\end{array}$ & $\begin{array}{c}-0.04 \\
(0.04)\end{array}$ & $\begin{array}{c}0.06 \\
(0.04)\end{array}$ \\
\hline Liberal $x$ Crisis Election & $\begin{array}{c}0.02 \\
(0.07)\end{array}$ & $\begin{array}{c}0.19 \\
(0.19)\end{array}$ & $\begin{array}{c}0.002 \\
(0.04)\end{array}$ & $\begin{array}{c}-0.05 \\
(0.04)\end{array}$ & $\begin{array}{c}0.07^{*} \\
(0.04)\end{array}$ \\
\hline Moderate Left x Crisis Election & $\begin{array}{c}0.03 \\
(0.06)\end{array}$ & $\begin{array}{c}0.05 \\
(0.17)\end{array}$ & $\begin{array}{c}0.01 \\
(0.04)\end{array}$ & $\begin{array}{c}-0.03 \\
(0.04)\end{array}$ & $\begin{array}{c}0.06^{*} \\
(0.03)\end{array}$ \\
\hline Far Left $\mathrm{x}$ Crisis Election & $\begin{array}{c}0.01 \\
(0.06)\end{array}$ & $\begin{array}{c}-0.22 \\
(0.20)\end{array}$ & $\begin{array}{c}-0.01 \\
(0.04)\end{array}$ & $\begin{array}{c}-0.06 \\
(0.04)\end{array}$ & $\begin{array}{l}0.07^{* *} \\
(0.03)\end{array}$ \\
\hline Green $x$ Crisis Election & $\begin{array}{c}-0.01 \\
(0.07)\end{array}$ & $\begin{array}{c}0.01 \\
(0.19)\end{array}$ & $\begin{array}{c}-0.02 \\
(0.05)\end{array}$ & $\begin{array}{c}-0.01 \\
(0.04)\end{array}$ & $\begin{array}{c}0.03 \\
(0.04)\end{array}$ \\
\hline Other $\mathrm{x}$ Crisis Election & $\begin{array}{c}0.03 \\
(0.07)\end{array}$ & $\begin{array}{c}-0.13 \\
(0.21)\end{array}$ & $\begin{array}{c}0.005 \\
(0.05)\end{array}$ & $\begin{array}{c}-0.03 \\
(0.05)\end{array}$ & $\begin{array}{c}0.05 \\
(0.04)\end{array}$ \\
\hline Moderate Left x Unemployment (t-1) & & $\begin{array}{c}-0.01 \\
(0.02)\end{array}$ & & & \\
\hline Crisis Election $\mathrm{x}$ Unemployment $(\mathrm{t}-1)$ & & $\begin{array}{c}-0.004 \\
(0.02)\end{array}$ & & & \\
\hline Mod Left x Crisis x Unempl (t-1) & & $\begin{array}{c}0.003 \\
(0.02)\end{array}$ & & & \\
\hline Constant & $\begin{array}{l}0.39^{* * *} \\
(0.09)\end{array}$ & $\begin{array}{l}0.35^{* *} \\
(0.14) \\
\end{array}$ & $\begin{array}{l}0.28^{* * *} \\
(0.06) \\
\end{array}$ & $\begin{array}{c}0.02 \\
(0.06) \\
\end{array}$ & $\begin{array}{c}0.08^{*} \\
(0.05)\end{array}$ \\
\hline Observations & 198 & 198 & 198 & 198 & 198 \\
\hline Log Likelihood & 65.23 & 27.95 & 136.37 & 138.57 & 163.26 \\
\hline Akaike Inf. Crit. & -66.46 & 34.10 & -208.74 & -213.14 & -262.53 \\
\hline Bayesian Inf. Crit. & 33.31 & 170.77 & -108.96 & -113.37 & -162.75 \\
\hline
\end{tabular}

Note: Country fixed effects are included in the models but not shown. Similarly, three-way interaction terms for other party families are included in model 2 but not shown. 
Still, it is important to disaggregate these changes into the three categories identified above. Figure 2 plots the salience of these issues separately for social democratic parties $9^{9}$ It indicates that the crisis did not systematically change party competition for welfare and economic liberalism. Generally, the salience of issues relating to the welfare state is higher in Northern than in Southern European countries, which is confirmed by the country fixed effects in model 3 that are not shown in the table. Except in Italy, this general divide between Northern and Southern Europe survived the Great Recession, suggesting that differences in salience between countries might reflect deeper structural differences between the two regions (e.g. different welfare state traditions). At the same time, some social democratic parties increased the salience of economic liberalism during the crisis whereas their sister parties in other countries decreased the salience. Thus, there is not a single pattern that captures changes in salience across all countries, which is confirmed by the regression analyses in model 3 and 4 of table 2 . However, model 5 of the same table shows that this is not true for the third category. The results indicate that moderate right-wing parties addressed issues relating to budgetary rigour more than other parties before 2008, but that social democratic parties, liberal, and far left parties increased the salience of budgetary rigour after 2008. As shown in figure, the salience of budgetary issues increased for moderate centre-left parties in nearly all countries, as expected by hypothesis 3a. In sum, this suggests that social democratic parties increasingly spoke about budgetary issues during the crisis, but in the absence of evidence about the positions of social democratic parties it is not clear whether this happened because social democratic parties opposed or supported budgetary rigour ${ }^{10}$ Therefore, I now turn towards analysing the positions of social democratic parties.

\section{Social Democratic Parties and the Crisis: Changes in Issue Positions}

The economic crisis did not only change the salience of economic issues, but it also influenced the positions that parties took on these issues. Figure 3 compares the left-right position before and after 2008 for the centre-left and centre-right parties. It illustrates that every social democratic party shifted to the left after 2008, except the Labour Party in Ireland and the PvDA in the Netherlands. On average, these parties shifted their aggregate left-right position by 0.15 points. Furthermore, in most countries the moderate right as well as other parties (not shown in figure 3) moved in the opposite direction

\footnotetext{
${ }^{9}$ Appendix 6 shows the nominal changes for each issue category. In appendix 7 parties are clustered according to these changes.

${ }^{10}$ These effects were again not systematically affected by the depth of the crisis. The three-way interaction used above is not significant for any of the categories, as shown in appendix 8 .
} 
Figure 2: Salience of Different Economic Issues for Social Democratic Parties by Country

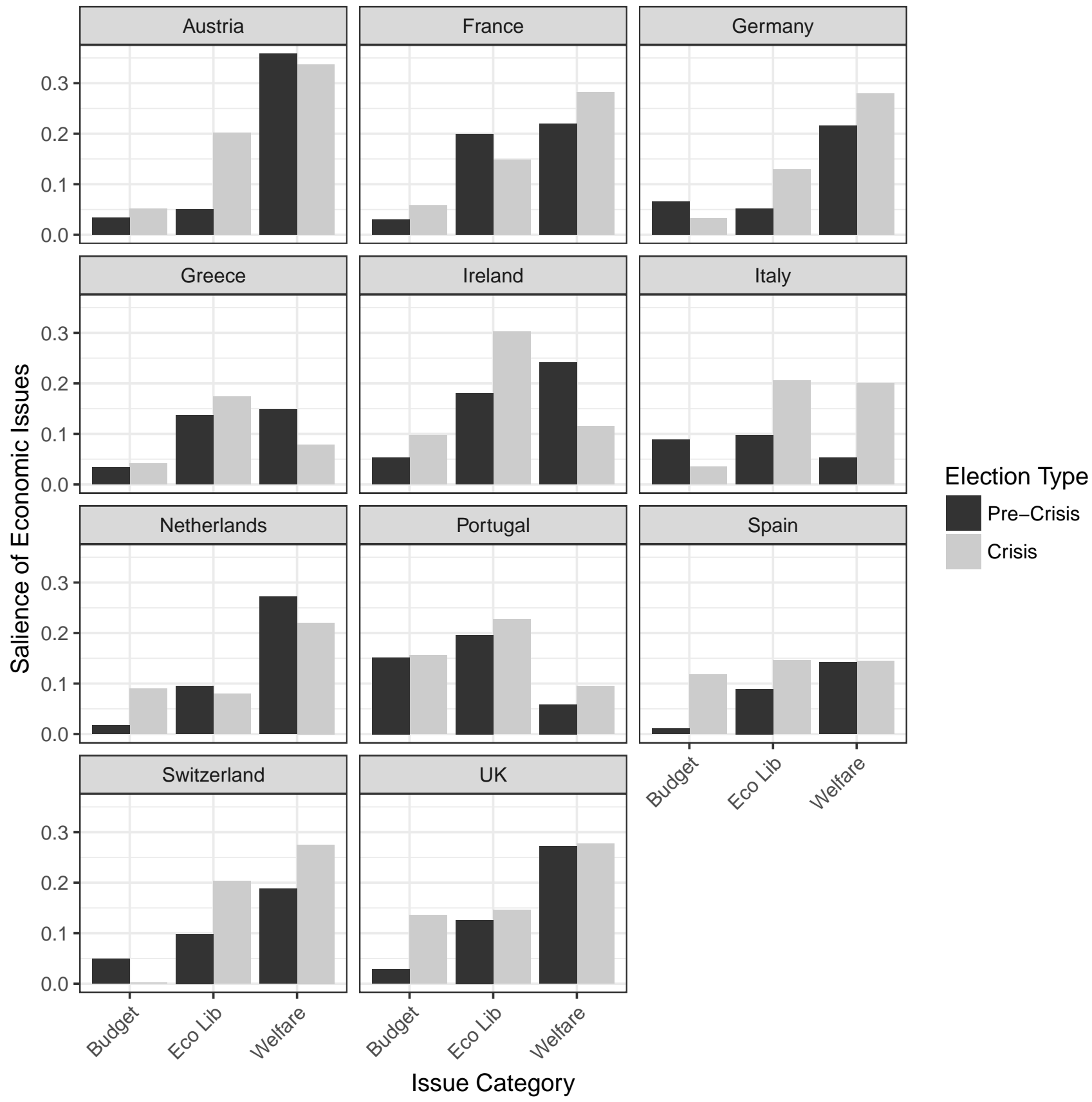

as social democratic parties. Hence, there is evidence that both hypotheses $2 \mathrm{a}$ and $2 \mathrm{~b}$ are true: the crisis led to a divergence between mainstream parties and, thereby, partly reversed the neoliberal convergence among mainstream parties that had occurred prior to the crisis.

In order to test whether these differences are statistically significant, I again use regression analysis. The results in model 1 of table 3 show that the moderate left- and right-wing parties indeed had programmes that were very similar prior to the crisis because the coefficient for moderate left-wing parties is not statistically significant when the 
Figure 3: Average Party Positions on Economic Issues by Party Family by Country

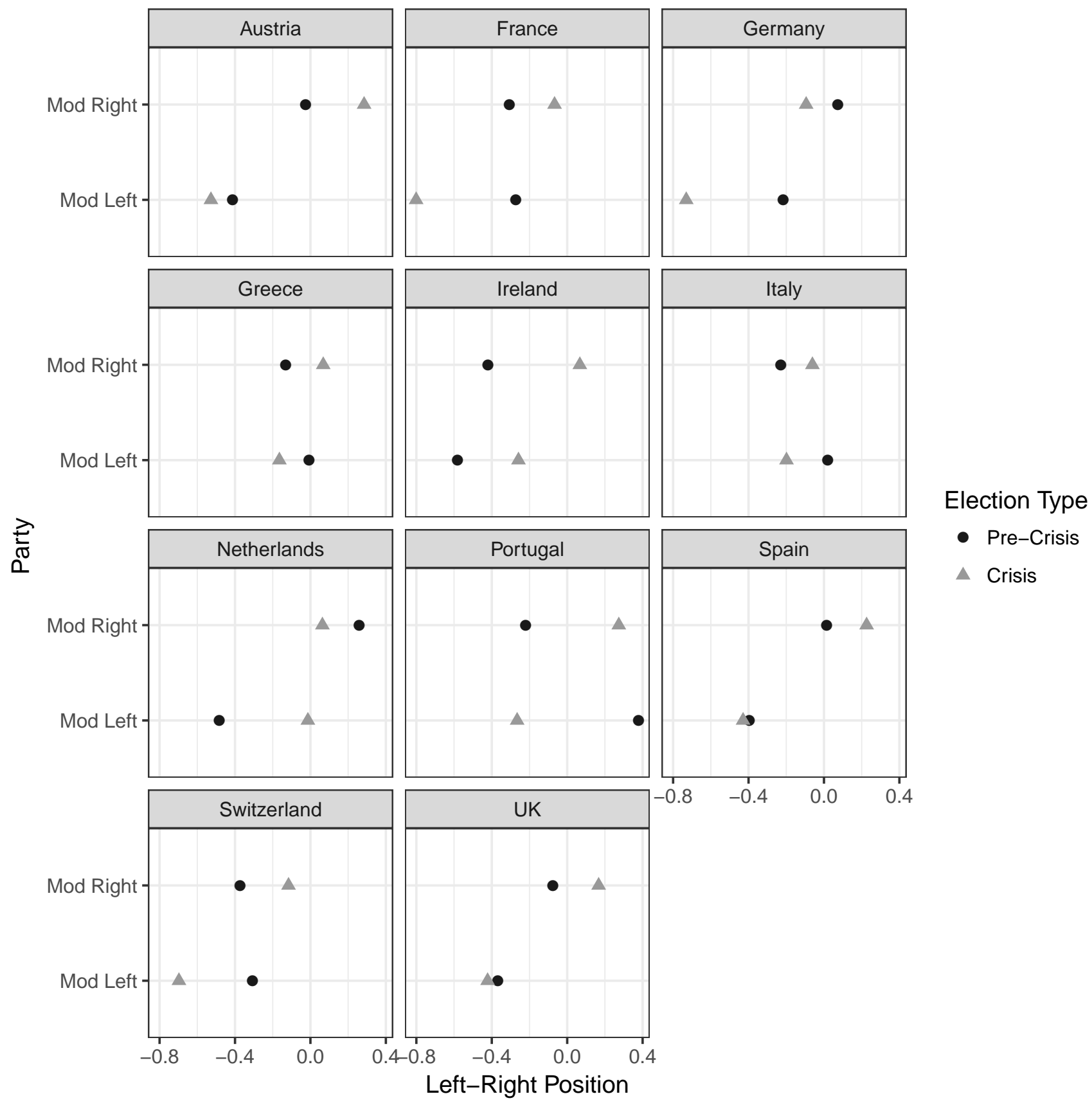

moderate right is used as the reference category. The differences between mainstream parties on economic issues had all but eroded and only far left parties had programmes that were significantly different from the mainstream in economic terms. However, the Great Recession changed this picture. As indicated by the interaction term, social democratic parties shifted leftwards and competed on a programme that was different from the programme of the moderate right. This is true even when controlling for other factors that could potentially influence a party's position on the left-right dimension of political conflict, including economic conditions and potential constraints from government responsibility. Thus, there is evidence that the Great Recession ended the neoliberal con- 
vergence, i.e. parties distinguished themselves again by different economic positions, as partisan theory expects (e.g. Hibbs, 1977).

Table 3: GLS Regression - Left Right Positions of Different Party Families

\begin{tabular}{|c|c|c|c|c|c|}
\hline & \multicolumn{5}{|c|}{ Dependent Variable } \\
\hline & $\begin{array}{c}\text { Aggregate I } \\
(1)\end{array}$ & $\begin{array}{c}\text { Aggregate II } \\
(2)\end{array}$ & $\begin{array}{c}\text { Welfare } \\
(3)\end{array}$ & $\begin{array}{c}\text { Eco Lib } \\
(4)\end{array}$ & $\begin{array}{c}\text { Budget } \\
\text { (5) }\end{array}$ \\
\hline Far Right & $\begin{array}{c}0.21 \\
(0.17)\end{array}$ & $\begin{array}{c}-0.48 \\
(0.62)\end{array}$ & $\begin{array}{c}0.10 \\
(0.21)\end{array}$ & $\begin{array}{l}0.43^{*} \\
(0.24)\end{array}$ & $\begin{array}{c}0.17 \\
(0.28)\end{array}$ \\
\hline Liberal & $\begin{array}{c}0.22 \\
(0.17)\end{array}$ & $\begin{array}{c}-0.04 \\
(0.52)\end{array}$ & $\begin{array}{c}0.12 \\
(0.20)\end{array}$ & $\begin{array}{c}0.32 \\
(0.23)\end{array}$ & $\begin{array}{c}0.03 \\
(0.28)\end{array}$ \\
\hline Moderate Left & $\begin{array}{c}0.05 \\
(0.14)\end{array}$ & $\begin{array}{c}-0.12 \\
(0.46)\end{array}$ & $\begin{array}{l}0.07 \\
(0.17)\end{array}$ & $\begin{array}{c}0.12 \\
(0.19)\end{array}$ & $\begin{array}{c}0.02 \\
(0.23)\end{array}$ \\
\hline Far Left & $\begin{array}{c}-0.39^{* * *} \\
(0.14)\end{array}$ & $\begin{array}{c}-0.70 \\
(0.57)\end{array}$ & $\begin{array}{r}-0.32^{*} \\
(0.17)\end{array}$ & $\begin{array}{c}-0.53^{* * *} \\
(0.20)\end{array}$ & $\begin{array}{c}-0.11 \\
(0.24)\end{array}$ \\
\hline Green & $\begin{array}{c}0.04 \\
(0.17)\end{array}$ & $\begin{array}{c}0.13 \\
(0.52)\end{array}$ & $\begin{array}{c}-0.22 \\
(0.21)\end{array}$ & $\begin{array}{c}0.16 \\
(0.24)\end{array}$ & $\begin{array}{c}-0.23 \\
(0.28)\end{array}$ \\
\hline Other & $\begin{array}{c}-0.21 \\
(0.17)\end{array}$ & $\begin{array}{c}0.20 \\
(0.55)\end{array}$ & $\begin{array}{c}-0.18 \\
(0.21)\end{array}$ & $\begin{array}{c}0.09 \\
(0.24)\end{array}$ & $\begin{array}{c}-0.29 \\
(0.29)\end{array}$ \\
\hline Crisis Election & $\begin{array}{l}0.28^{* *} \\
(0.12)\end{array}$ & $\begin{array}{c}0.35 \\
(0.37)\end{array}$ & $\begin{array}{l}0.34^{* *} \\
(0.15)\end{array}$ & $\begin{array}{c}0.07 \\
(0.17)\end{array}$ & $\begin{array}{l}0.39^{*} \\
(0.20)\end{array}$ \\
\hline Unemployment $(\mathrm{t}-1)$ & $\begin{array}{c}0.002 \\
(0.02)\end{array}$ & $\begin{array}{c}0.03 \\
(0.05)\end{array}$ & $\begin{array}{l}0.04^{*} \\
(0.02)\end{array}$ & $\begin{array}{c}-0.002 \\
(0.02)\end{array}$ & $\begin{array}{r}-0.05^{*} \\
(0.03)\end{array}$ \\
\hline Inflation (t-1) & $\begin{array}{l}-0.06 \\
(0.05)\end{array}$ & $\begin{array}{c}-0.03 \\
(0.05)\end{array}$ & $\begin{array}{l}0.03 \\
(0.06)\end{array}$ & $\begin{array}{c}-0.09 \\
(0.07)\end{array}$ & $\begin{array}{c}-0.12 \\
(0.08)\end{array}$ \\
\hline Gov Deficit (t-1) & $\begin{array}{c}0.01 \\
(0.01)\end{array}$ & $\begin{array}{c}0.02 \\
(0.01)\end{array}$ & $\begin{array}{l}0.002 \\
(0.02)\end{array}$ & $\begin{array}{c}0.01 \\
(0.02)\end{array}$ & $\begin{array}{c}-0.03 \\
(0.02)\end{array}$ \\
\hline GDP Growth (t-1) & $\begin{array}{c}-0.004 \\
(0.01)\end{array}$ & $\begin{array}{r}-0.003 \\
(0.01)\end{array}$ & $\begin{array}{r}-0.004 \\
(0.01)\end{array}$ & $\begin{array}{r}-0.005 \\
(0.01)\end{array}$ & $\begin{array}{c}0.02 \\
(0.01)\end{array}$ \\
\hline Gov Debt (t-1) & $\begin{array}{c}-0.003 \\
(0.003)\end{array}$ & $\begin{array}{c}-0.002 \\
(0.003)\end{array}$ & $\begin{array}{l}-0.01^{*} \\
(0.003)\end{array}$ & $\begin{array}{c}-0.004 \\
(0.004)\end{array}$ & $\begin{array}{c}0.001 \\
(0.004)\end{array}$ \\
\hline Government (t-1) & $\begin{array}{l}0.08 \\
(0.09)\end{array}$ & $\begin{array}{l}0.08 \\
(0.10)\end{array}$ & $\begin{array}{c}0.16 \\
(0.11)\end{array}$ & $\begin{array}{c}0.05 \\
(0.13)\end{array}$ & $\begin{array}{l}0.21 \\
(0.15)\end{array}$ \\
\hline Prime Minister (t-1) & $\begin{array}{c}0.09 \\
(0.11)\end{array}$ & $\begin{array}{c}0.10 \\
(0.12)\end{array}$ & $\begin{array}{c}-0.11 \\
(0.14)\end{array}$ & $\begin{array}{c}0.10 \\
(0.16)\end{array}$ & $\begin{array}{c}-0.05 \\
(0.19)\end{array}$ \\
\hline Far Right $\mathrm{x}$ Crisis Election & $\begin{array}{c}-0.23 \\
(0.20)\end{array}$ & $\begin{array}{c}0.56 \\
(0.66)\end{array}$ & $\begin{array}{c}-0.06 \\
(0.24)\end{array}$ & $\begin{array}{c}-0.64^{* *} \\
(0.28)\end{array}$ & $\begin{array}{c}-0.25 \\
(0.33)\end{array}$ \\
\hline Liberal x Crisis Election & $\begin{array}{c}-0.08 \\
(0.20)\end{array}$ & $\begin{array}{c}0.52 \\
(0.56)\end{array}$ & $\begin{array}{c}0.04 \\
(0.24)\end{array}$ & $\begin{array}{c}-0.04 \\
(0.28)\end{array}$ & $\begin{array}{c}-0.13 \\
(0.33)\end{array}$ \\
\hline Moderate Left x Crisis Election & $\begin{array}{l}-0.47^{* * *} \\
(0.17)\end{array}$ & $\begin{array}{l}-0.28 \\
(0.50)\end{array}$ & $\begin{array}{c}-0.46^{* *} \\
(0.20)\end{array}$ & $\begin{array}{l}-0.56^{* *} \\
(0.23)\end{array}$ & $\begin{array}{c}-0.43 \\
(0.28)\end{array}$ \\
\hline Far Left $\mathrm{x}$ Crisis Election & $\begin{array}{l}-0.37^{* *} \\
(0.17)\end{array}$ & $\begin{array}{c}0.07 \\
(0.61)\end{array}$ & $\begin{array}{c}-0.25 \\
(0.20)\end{array}$ & $\begin{array}{c}-0.12 \\
(0.23)\end{array}$ & $\begin{array}{l}-0.86^{* * *} \\
(0.28)\end{array}$ \\
\hline Green x Crisis Election & $\begin{array}{c}-0.32 \\
(0.20)\end{array}$ & $\begin{array}{c}-0.33 \\
(0.56)\end{array}$ & $\begin{array}{l}-0.15 \\
(0.25)\end{array}$ & $\begin{array}{c}-0.26 \\
(0.28)\end{array}$ & $\begin{array}{c}-0.04 \\
(0.33)\end{array}$ \\
\hline Other x Crisis Election & $\begin{array}{c}0.17 \\
(0.21)\end{array}$ & $\begin{array}{c}-0.21 \\
(0.62)\end{array}$ & $\begin{array}{l}0.11 \\
(0.26)\end{array}$ & $\begin{array}{c}0.04 \\
(0.30)\end{array}$ & $\begin{array}{c}0.11 \\
(0.35)\end{array}$ \\
\hline Moderate Left $\mathrm{x}$ Unemployment ( $\mathrm{t}-1)$ & & $\begin{array}{c}0.02 \\
(0.06)\end{array}$ & & & \\
\hline Crisis Election x Unemployment (t-1) & & $\begin{array}{c}-0.02 \\
(0.05)\end{array}$ & & & \\
\hline Mod Left x Crisis x Unempl (t-1) & & $\begin{array}{c}-0.03 \\
(0.06)\end{array}$ & & & \\
\hline Constant & $\begin{array}{c}-0.12 \\
(0.25)\end{array}$ & $\begin{array}{c}-0.38 \\
(0.43)\end{array}$ & $\begin{array}{r}-0.58^{*} \\
(0.30)\end{array}$ & $\begin{array}{c}0.23 \\
(0.35) \\
\end{array}$ & $\begin{array}{r}0.78^{*} \\
(0.41) \\
\end{array}$ \\
\hline Observations & 198 & 198 & 198 & 198 & 198 \\
\hline Log Likelihood & -112.03 & -139.62 & -146.37 & -169.33 & -196.94 \\
\hline Akaike Inf. Crit. & 288.07 & 369.24 & 356.74 & 402.66 & 457.87 \\
\hline Bayesian Inf. Crit. & 387.84 & 505.90 & 456.52 & 502.43 & 557.65 \\
\hline
\end{tabular}

Note: Country fixed effects are included in the models but not shown. Similarly, three-way interaction terms for other party families are included in model 2 but not shown. 
Model 2 in table 3 examines whether these changes were conditional on the depth of the crisis. Given that the three-way interaction term is not statistically significant, this does not seem to be the case. Social democratic parties shifted to the left independently of the depth of the crisis and, thus, there is no evidence for hypothesis 4 . Instead, the crisis was apparently deep enough to induce social democratic parties to shift their positions in all the countries studied here. Still, it remains unclear whether this shift occurred with respect to all the issues category identified above.

Figure 4 plots the attitudes towards these issues on a scale from -1 to +1 , where +1 means that a party is completely opposed to welfare, completely in favour of economic liberalism or completely in favour of budgetary rigour, respectively. The graph shows that many moderate left-wing parties had been strongly pro welfare even before 2008, but as the welfare state came under attack during the economic crisis, social democratic parties defended it even more resolutely. Only the Dutch PvdA and the Italian PD shifted to the right and adopted a more ambiguous position towards the welfare state during the crisis. This picture is similar for the position of social democratic parties towards economic liberalism, except that many social democratic parties had more ambiguous positions towards economic liberalism before the crisis. Reflecting the policies of the Third Way, social democratic parties in Italy, Greece, the Netherlands, Portugal, Spain, Switzerland, and the UK were in favour or had an ambivalent position towards economic liberalism prior to 2008. The social democratic parties in the other countries were not clearly opposed to it, either. However, after 2008 social democratic parties shifted strongly towards the left, thereby moving closer to their core ideology again. Thus, most social democratic parties campaigned again for the welfare state and against economic liberalism during the crisis.

The positions of social democratic parties with regards to fiscal policy do not follow the same pattern. Instead, many social democratic parties changed their positions on budgetary rigour in the opposite direction. Many parties already had an ambivalent position towards fiscal policies before the crisis, but some became even more supportive of budgetary rigour during the crisis. The centre-left parties in France and Portugal were the only parties that adopted a weakly negative position towards budgetary rigour during the crisis after they had shifted their positions towards the left compared to the pre-crisis period. Nonetheless, their positions on budgetary rigour were still a lot further to the right compared to their positions on welfare and economic liberalism, as shown in figure 4. Therefore, in general the centre-left mirrored the positions of the political right and campaigned for lower government budget deficits and government debt in response to the crisis. Contrary to existing evidence from parliamentary speeches (Maatsch, 2014), this happened in both creditor and debtor countries. 
Figure 4: Average Positions of Social Democratic Parties on Different Economic Issues by Country

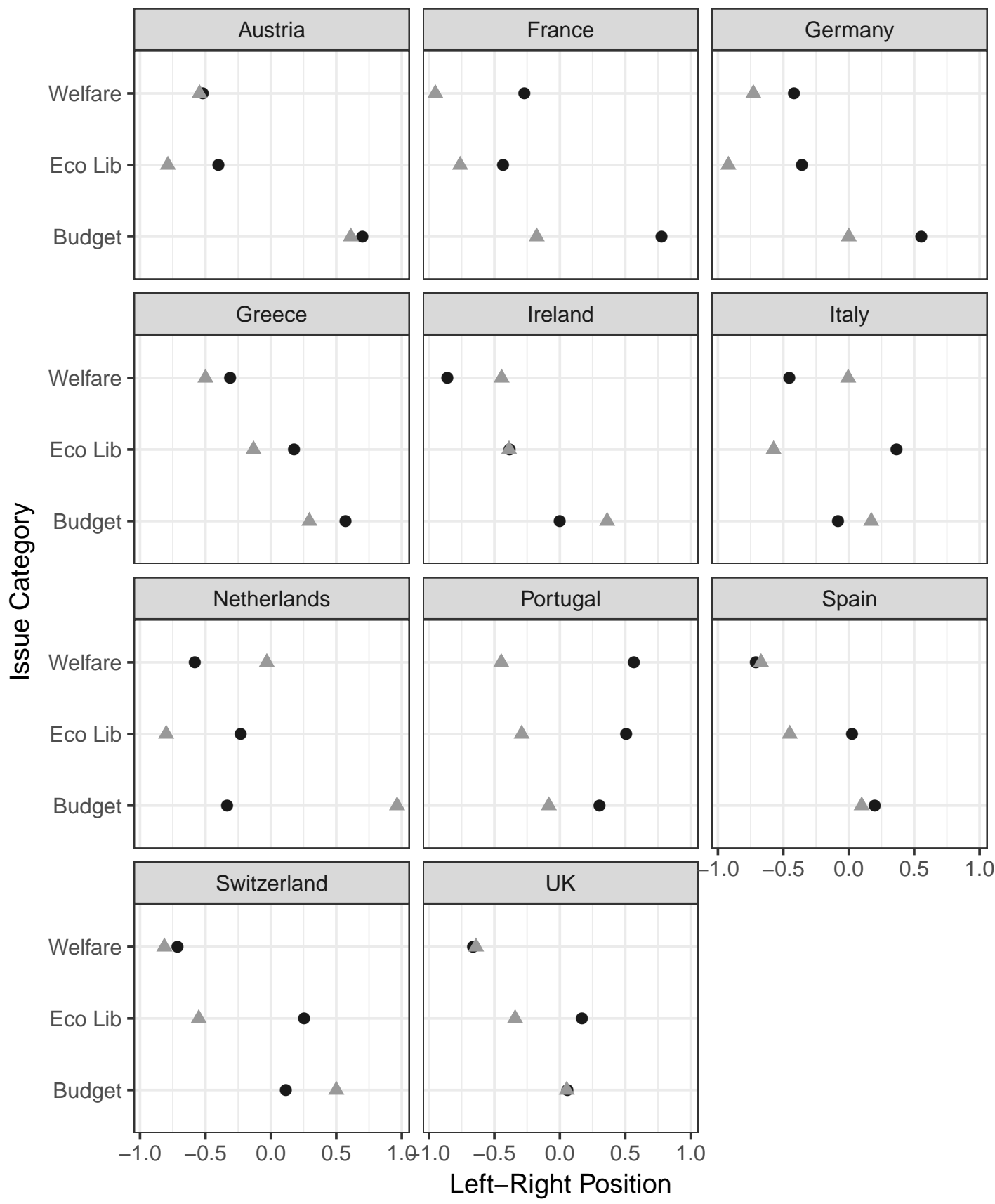

Election Type

- Pre-Crisis

$\triangle$ Crisis

Again, these impressions can be substantiated by regression analysis. For this purpose, I repeat the analysis from above and use the party's average position on each individual issue category as dependent variables. The results show that prior to 2008, social democratic parties had not campaigned on programmes that were significantly different from other parties. However, during the crisis social democratic parties changed their programmes with regard to both welfare and economic liberalism, as indicated in model 3 and 4 of table 3. Reflecting the new-found scepticism of the moderate left towards (financial) markets, this shift was particularly large for economic liberalism, as suggested 
above. In contrast, the crisis did not lead to a differentiation between between centre-left and centre-right parties with regards to budgetary policies. The crisis induced centreright parties to become more 'austere', which is indicated by the positive and statistically significant dummy variable in model 5 of table 3 . At the same time, the interaction term is not statistically significant, indicating that social democratic parties had no position on austerity that was significantly different from the position of centre-right parties after 2008. Importantly, this happened across most countries and did not depend on the depth of crisis (appendix 8). Consequently, there is evidence that hypothesis 3b is true, indicating that the Great Recession did not affect all aspects of party competition (on economic issues) equally. Contrary to the common assumption that parties bundle issues together, which leads to consistent policy packages, social democratic parties had a differentiated response to the crisis as they adopted positions with regard to different issue categories that are usually considered to be on different ends of the left-right spectrum.

Figure 5: Average Positions of Social Democratic Parties on Different Economic Issues by Election Type

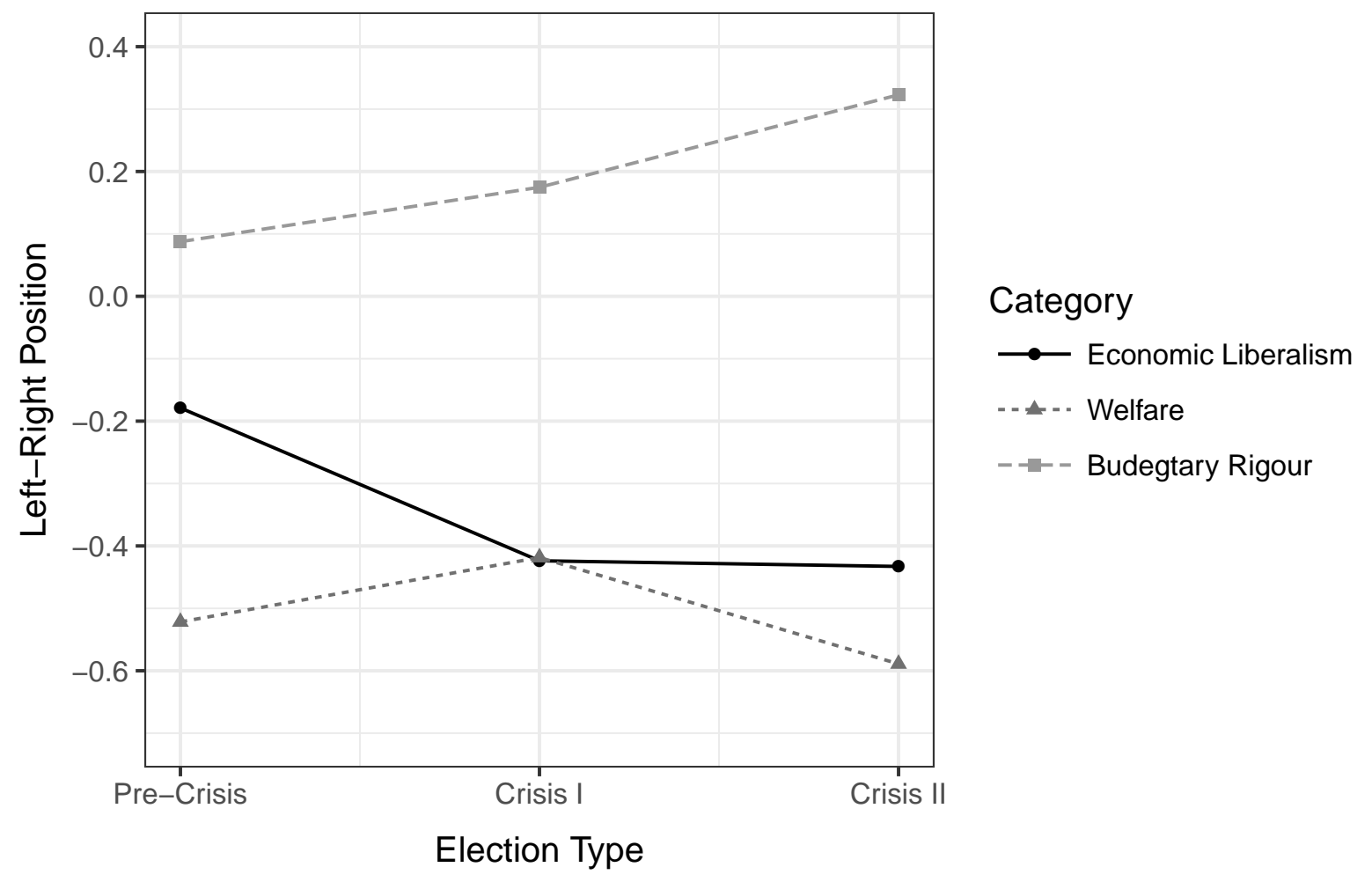

Note: Countries that only had one election from 2009 to 2015 are not shown in the graph. The two elections in Greece in 2012 are treated as a single observation.

Finally, for countries with more than one election during the economic crisis, we can analyse how stable the positions of social democratic parties were during the crisis. Figure 5 shows the average position of social democratic parties in eight countries by election type. It suggests that the most important change in the programmes of social democratic 
parties happened before the first crisis election: they shifted towards the left on economic liberalism and, hence, their positions on welfare and economic liberalism converged. At the same time, they slightly shifted towards the right on budgetary rigour. Prior to the second crisis elections, social democratic parties followed up on these initial shifts by shifting further to the left with regard to economic liberalism, while shifting further to the right on budgetary rigour. This is further evidence that social democratic parties turned away from their Third Way during the Great Recession, but that they did not attempt to engineer a paradigm shift with regard to fiscal policies. Importantly, this created some inconsistencies within their programmes: while austerity might be compatible with state intervention (e.g. minimum wage or financial regulation), defending the welfare state is not. Instead, austerity usually leads to welfare state retrenchment Armingeon et al. 2016), which would make it very difficult for social democratic parties to implement their programmes if they were voted into government again. Further evidence from countries with additional elections during the crisis suggests that there are two different ways that social democratic parties might resolve this tension (as shown in appendix 9). On the one hand, the PS in Portugal shifted its position on austerity towards the left prior to the election in 2015. On the other hand, PASOK in Greece shifted its position on economic liberalism and welfare to the centre again in 2015 after the far left party Syriza had successfully established itself as the main actor on the left of the party system. This indicates that social democratic parties are likely to further adjust their programmatic positions in the wake of the crisis but that they might not resolve the internal tensions within their platforms in a uniform way across Europe.

\section{Conclusion}

In conclusion, the Great Recession systematically changed the platform on which the European moderate left competed in elections. In terms of salience, social democratic parties paid more attention towards economic issues again, but this was mirrored by a general increase of salience for all parties. Centre-left parties moved in tandem with centre-right and liberal parties and emphasised economic issues more during the Great Recession. In this way, the crisis halted a previous trend that saw mainstream parties appeal to cultural issues prior to the crisis. However, in terms of positions, left-wing parties set themselves apart from other parties in response to the Great Recession. Despite the popular perception that the left was missing during the crisis and failed to defend its core ideology during the crisis, my findings paint a more nuanced picture. In almost all countries studied here, social democratic parties defended the welfare state and became more sceptical of economic liberalism. Thereby, the centre-left retracted large parts of its Third Way policies and reversed the neoliberal convergence that scholars had observed 
prior to the Great Recession. Yet, these parties did not shift to the left in response to the crisis with regard to all categories. Importantly, social democratic parties accepted the need for fiscal consolidation and budgetary rigour, which created some tensions within their platforms. These tensions are signs of a deep identity crisis that social democratic parties faced in the wake of the economic crisis and that many of them have failed to resolve until this day.

However, at this point there are already at least three implications from the evidence presented in this paper that are worth noting. First, the Great Recession initiated a critical juncture for party competition in Europe. While my evidence shows that parties changed the salience that they attribute to economic issues in tandem, they did change their programmes in different directions in response to the economic shock. Although we cannot be completely certain that parties will not shift back to their pre-crisis position, it confirms that parties are strategic actors that respond to changes in their economic context. Second, the evidence also shows that parties do not always change their positions in the same direction on all issues categories. Consequently, we need to be careful when studying party programmes in aggregate terms: although it is certainly useful to rank parties based on their left-right positions, scholars also need to appreciate that parties sometimes bundle policy packages together that do not fall on the same end of the leftright dimension. Hence, we should pay more attention towards studying the positions of parties on individual issues and analyse how the positions of parties with respect to different issues relate to each other. Finally, social democratic parties adopted a rather inconsistent programme during the Great Recession. In particular, the budgetary policies that social democratic parties have put forward can neither be easily squared with their support for the welfare state nor with their own core ideology. Therefore, we need further research to understand why social democratic parties accepted austerity in response to the crisis. This research would not only shed light on the distributive conflicts associated with fiscal policies, but it might also help us to make sense of the current crisis of social democratic parties in Europe. 


\section{References}

Adams, J., Haupt, A. B., and Stoll, H. (2009). What Moves Parties? The Role of Public Opinion and Global Economic Conditions in Western Europe. Comparative Political Studies, 42(5):611-639.

Allan, J. P. and Scruggs, L. (2004). Political Partisanship and Welfare State Reform in Advanced Industrial Societies. American Journal of Political Science, 48(3):496-512.

Armingeon, K., Guthmann, K., and Weisstanner, D. (2016). Choosing the path of austerity: how parties and policy coalitions influence welfare state retrenchment in periods of fiscal consolidation. West European Politics, 39(4):628-647.

Balls, E. (2014). Speech to the Fabian Society New Year conference, 25 January 2014. Available online at http://labourlist.org/2014/01/ full-text-ed-balls-commits-labour-to-budget-surplus-and-announces-50p-tax-rate-pla [accessed on 12 October 2016].

Bean, C. (2010). Joseph Schumpeter Lecture: The Great Moderation, the Great Panic, and the Great Contraction. Journal of the European Economic Association, 8(2-3):289325.

Bélanger, E. and Meguid, B. M. (2008). Issue salience, issue ownership, and issue-based vote choice. Electoral Studies, 27(3):477-491.

Berger, S. (2000). Globalization and politics. Annual Review of Political Science, 3(1):4362.

Blanchard, O., Dell'ariccia, G., and Mauro, P. (2010). Rethinking Macroeconomic Policy. Journal of Money, Credit and Banking, 42:199-215.

Blyth, M. (2002). Great Transformations: Economic Ideas and Institutional Change in the Twentieth Century. Cambridge University Press, Cambridge.

Boix, C. (1998). Political Parties, Growth and Equality: Conservative and Social Democratic Economic Strategies in the World Economy. Cambridge University Press, Cambridge.

Budge, I. (1994). A New Spatial Theory of Party Competition: Uncertainty, Ideology and Policy Equilibria Viewed Comparatively and Temporally. British Journal of Political Science, 24(4):443-467.

Budge, I. and Farlie, D. (1983). Explaining and Predicting Elections: Issue Effects and Party Strategies in Twenty-Three Democracies. Allen \& Unwin, London; Boston. 
Budge, I., Klingemann, H.-D., Volkens, A., and Bara, J., editors (2001). Mapping Policy Preferences: Estimates for Parties, Electors, and Governments, 1945-1998. Oxford University Press, Oxford; New York.

Burgoon, B. (2001). Globalization and Welfare Compensation: Disentangling the Ties That Bind. International Organization, 55(3):509-551.

Callaghan, J. (2000). The Retreat of Social Democracy. Manchester University Press, Manchester; New York.

Capoccia, G. (2015). Critical Junctures and Institutional Change. In Mahoney, J. and Thelen, K., editors, Advances in Comparative Historical Analysis, pages 147-179. Cambridge University Press, Cambridge.

Capoccia, G. and Kelemen, R. D. (2007). The study of critical junctures: Theory, narrative, and counterfactuals in historical institutionalism. World Politics, 59(03):341-369.

Clements, B., Nanou, K., and Real-Dato, J. (2017). Economic crisis and party responsiveness on the left-right dimension in the european union. Party Politics.

Collier, R. B. and Collier, D. (1991). Shaping the Political Arena: Critical Junctures, the Labor Movement, and Regime Dynamics in Latin America. Princeton University Press.

Dalton, R. J. (2016). Stability and change in party issue positions: The 2009 and 2014 European elections. Electoral Studies, 44:525-534.

Dalton, R. J. and McAllister, I. (2015). Random Walk or Planned Excursion? Continuity and Change in the Left-Right Positions of Political Parties. Comparative Political Studies, 48(6):759-787.

Dolezal, M., Ennser-Jedenastik, L., Müller, W. C., and Winkler, A. K. (2014). How parties compete for votes: A test of saliency theory. European Journal of Political Research, 53(1):57-76.

Downs, A. (1957). An Economic Theory of Democracy. Harber \& Row, New York.

English, P., Grasso, M. T., Buraczynska, B., Karampampas, S., and Temple, L. (2016). Convergence on Crisis? Comparing Labour and Conservative Party Framing of the Economic Crisis in Britain, 2008-14. Politics \& Policy, 44(3):577-603.

Ezrow, L., De Vries, C., Steenbergen, M., and Edwards, E. (2011). Mean voter representation and partisan constituency representation: Do parties respond to the mean voter position or to their supporters? Party Politics, 17(3):275-301. 
Franklin, M. N., Mackie, T. T., and Valen, H. (1992). Electoral Change: Responses to Evolving Social and Attitudinal Structures in Western Countries. Cambridge University Press, Cambridge; New York.

Garrett, G. and Lange, P. (1991). Political Responses to Interdependence: What's "Left" for the Left? International Organization, 45(4):539-564.

Gemenis, K. (2013). What to Do (and Not to Do) with the Comparative Manifestos Project Data. Political Studies, 61:3-23.

Glyn, A., editor (2001). Social Democracy in Neoliberal Times: The Left and Economic Policy since 1980. Oxford University Press, Oxford.

Gourevitch, P. (1986). Politics in Hard Times: Comparative Responses to International Economic Crises. Cornell University Press, Ithaca, NY.

Green, J. and Hobolt, S. B. (2008). Owning the issue agenda: Party strategies and vote choices in British elections. Electoral Studies, 27(3):460-476.

Greene, W. H. (2012). Econometric Analysis. Pearson Addison Wesley, Harlow; New York, seventh edition edition.

Hall, P. (2013). The Political Origins of Our Economic Discontents: Contemporary Adjustment Problems in Historical Perspective. In Kahler, M. and Lake, D. A., editors, Politics in the New Hard Times: The Great Recession in Comparative Perspective, pages 129-149. Cornell University Press, Ithaca, NY.

Hall, P. A. (1993). Policy Paradigms, Social Learning, and the State: The Case of Economic Policymaking in Britain. Comparative Politics, 25(3):275.

Haupt, A. B. (2010). Parties' Responses to Economic Globalization What is Left for the Left and Right for the Right? Party Politics, 16(1):5-27.

Helbling, M. and Tresch, A. (2011). Measuring party positions and issue salience from media coverage: Discussing and cross-validating new indicators. Electoral Studies, 30(1):174-183.

Hernández, E. and Kriesi, H. (2016). The electoral consequences of the financial and economic crisis in Europe. European Journal of Political Research, 55(2):203-224.

Hibbs, Jr., D. A. (1977). Political Parties and Macroeconomic Policy. The American Political Science Review, 71(4):1467-1487.

Hooghe, L. and Marks, G. (2009). A postfunctionalist theory of European integration: From permissive consensus to constraining dissensus. British Journal of Political Science, 39(1):1-23. 
Hooghe, L. and Marks, G. (2018). Cleavage theory meets Europe's crises: Lipset, Rokkan, and the transnational cleavage. Journal of European Public Policy, 25(1):109-135.

Huber, J. D. and Powell, G. B. (1994). Congruence between citizens and policymakers in two visions of liberal democracy. World Politics, 46(03):291-326.

Kitschelt, H. (1994). The Transformation of European Social Democracy. Cambridge University Press, Cambridge.

Kleinnijenhuis, J., de Ridder, J. A., and Rietberg, E. M. (1997). Reasoning in Economic Discourse: An Application of the Network Approach to the Dutch Press. In Roberts, C., editor, Text Analysis for the Social Sciences: Methods for Drawing Statistical Inferences from Texts and Transcripts. Mahwah: Erlbaum, pages 191-207. Erlbaum.

Kleinnijenhuis, J. and Pennings, P. (2001). Measurment of party positions on the basis of party programmes, media coverage and voter perceptions. In Laver, M., editor, Estimating the Policy Position of Political Actors, pages 162-182. Routledge, London.

Korpi, W. (1983). The Democratic Class Struggle. Routledge \& K. Paul, London; Boston.

Kraft, J. (2017). Social democratic austerity: the conditional role of agenda dynamics and issue ownership. Journal of European Public Policy, 24(10):1430-1449.

Kriesi, H., Grande, E., Dolezal, M., Helbling, M., Höglinger, D., Hutter, S., and Wüest, B. (2012). Political Conflict in Western Europe. Cambridge University Press, Cambridge.

Kriesi, H., Grande, E., Lachat, R., Dolezal, M., Bornschier, S., and Frey, T. (2008). West European Politics in the Age of Globalization. Cambridge University Press, Cambridge.

Lipset, S. M. and Rokkan, S. (1967). Party Systems and Voter Alignments: Cross National Perspectives. Free Press.

Maatsch, A. (2014). Are we all austerians now? An analysis of national parliamentary parties' positioning on anti-crisis measures in the eurozone. Journal of European Public Policy, 21(1):96-115.

Margalit, Y. (2013). Explaining Social Policy Preferences: Evidence from the Great Recession. American Political Science Review, 107(01):80-103.

Matthijs, M. (2011). Ideas and Economic Crises in Britain from Attlee to Blair (19452005). Routledge, New York, NY.

Matthijs, M. and McNamara, K. (2015). The Euro Crisis' Theory Effect: Northern Saints, Southern Sinners, and the Demise of the Eurobond. Journal of European Integration, $37(2): 229-245$. 
McDonald, M. D. and Budge, I. (2005). Elections, Parties, Democracy: Conferring the Median Mandate. Oxford University Press, Oxford.

Mishra, R. (1999). Globalization and the Welfare State. Edward Elgar, Cheltenham, UK; Northampton, MA.

Müler, W. C. and Strøm, K., editors (1999). Policy, Office, or Votes? How Political Parties in Western Europe Make Hard Decisions. Cambridge University Press, Cambridge; New York.

Münchau, W. (2015). Perplexing failure of Europe's centre-left. 20 September. Available online at http://www.ft.com/intl/cms/s/2/ 40c1903a-5dee-11e5-9846-de406ccb37f2.html\#axzz44qNx9uG9 [accessed 16 October 2016].

Otjes, S. (2016). Distinguishing welfare state reform and income redistribution. A twodimensional approach to the Dutch voter space on economic issues. Party Politics.

Otjes, S. and Katsanidou, A. (2017). Beyond Kriesiland: EU integration as a super issue after the Eurocrisis. European Journal of Political Research, 56:301-319.

Petrocik, J. R. (1996). Issue Ownership in Presidential Elections, with a 1980 Case Study. American Journal of Political Science, 40(3):825-850.

Petrocik, J. R., Benoit, W. L., and Hansen, G. J. (2003). Issue Ownership and Presidential Campaigning, 1952-2000. Political Science Quarterly, 118(4):599-626.

Piazza, J. (2001). De-Linking Labor Labor Unions and Social Democratic Parties under Globalization. Party Politics, 7(4):413-435.

Pierson, C. (2001). Hard Choices: Social Democracy in the Twenty-first Century. Polity Press; Blackwell, Oxford; Malden, MA.

Pierson, P. (2000). Increasing Returns, Path Dependence, and the Study of Politics. The American Political Science Review, 94(2):251.

Pontusson, J. and Raess, D. (2012). How (and why) is this time different? the politics of economic crisis in western europe and the united states. Annual Review of Political Science, $15: 13-33$.

Przeworski, A. and Sprague, J. D. (1986). Paper Stones: A History of Electoral Socialism. University of Chicago Press, Chicago.

Ross, F. (2000). 'Beyond Left and Right': The New Partisan Politics of Welfare. Governance, $13(2): 155-183$. 
Scharpf, F. W. (1987). Sozialdemokratische Krisenpolitik in Europa. Campus, Frankfurt.

Singer, M. (2011). When do voters actually think "It's the Economy"? Evidence from the 2008 presidential campaign. Electoral Studies, 30(4):621-632.

Social Democratic Party of Germany (2013). Das Wir Entscheidet: Das Regierungsprogramm 2013-2017. Available online at https://www3.spd.de/linkableblob/96686/ data/20130415_regierungsprogramm_2013_2017.pdf [accessed 12 October 2016].

Stephens, J. D. (1979). The Transition from Capitalism to Socialism. Macmillan, London.

Stimson, J. A. (1985). Regression in Space and Time: A Statistical Essay. American Journal of Political Science, 29(4):914-947.

Stimson, J. A., Mackuen, M. B., and Erikson, R. S. (1995). Dynamic Representation. The American Political Science Review, 89(3):543-565.

Strange, S. (1996). The Retreat of the State: The Diffusion of Power in the World Economy. Cambridge University Press, New York.

Strøm, K. (1990). A Behavioral Theory of Competitive Political Parties. American Journal of Political Science, 34(2):565.

The Economist (2016). Rose thou art sick. 2 April. Available online at http://www.economist.com/news/briefing/ 21695887-centre-left-sharp-decline-across-europe-rose-thou-art-sick [accessed 16 October 2016].

Traber, D., Giger, N., and Häusermann, S. (2017). How economic crises affect political representation: Declining party-voter congruence in times of constrained government. West European Politics.

Volkens, A., Lehmann, P., Matthieß, T., Merz, N., Regel, S., and Weßels, B. (2017). The Manifesto Data Collection. Manifesto Project (MRG/CMP/MARPOR) Version 2017a. Available online at https://doi.org/10.25522/manifesto.mpds.2017a [accessed 16 November 2017].

Wagner, M. and Meyer, T. M. (2014). Which Issues do Parties Emphasise? Salience Strategies and Party Organisation in Multiparty Systems. West European Politics, 37(5):1019-1045.

Ward, D., Kim, J. H., Graham, M., and Tavits, M. (2015). How Economic Integration Affects Party Issue Emphases. Comparative Political Studies, 48(10):1227-1259.

Ward, H., Ezrow, L., and Dorussen, H. (2011). Globalization, Party Positions, and the Median Voter. World Politics, 63(3):509-547. 